\title{
Conversion of Hospital Low Density Polyethylene Waste into Hydrocarbons Using Fly Ash as Catalyst \\ P. Premkumar ${ }^{1}$, C.G. Saravanan ${ }^{1 *}$, M. Gopalakrishnan ${ }^{2}$ \\ ${ }_{1 \& 1 *}$ Department of Mechanical Engineering. Annamalai University Annamalainagar, India. \\ ${ }^{2}$ Department of Chemistry. Annamalai University Annamalainagar, India.
}

\begin{abstract}
Hydrocarbons have been obtained from waste saline bottles, made of low density polyethylene (LDPE), by degradation using fly ash as catalyst. When cat/pol ratio was 0.1 $97 \%$ degradation was observed with $75 \%$ of oil formation. Increase in cat/pol ratio reduced the amount oil formed and increased the amount of gaseous hydrocarbons. Increase in cat/pol ratio reduced the reaction temperature and reaction time. The oil obtained was fractionated into the following four fractions viz., fraction boiling below $100{ }^{\circ} \mathrm{C}$, fraction boiling in the range $100-150{ }^{\circ} \mathrm{C}$, fraction boiling in the range $150-200{ }^{\circ} \mathrm{C}$ and fraction boiling above $200{ }^{\circ} \mathrm{C}$. In all cause the major fraction is that one boiling in the range 100 $150{ }^{\circ} \mathrm{C}$. The GCMS spectrum of this fractions shows that it contains large hydrocarbons with 4-9 carbons atoms. The physico-chemical properties of the three fractions boiling within 200 ${ }^{\circ} \mathrm{C}$ suggested that they can be used as substitute for diesel. The flame temperature of the flame produced by the burning gas was highest when cat/pol ratio was 0.2 .
\end{abstract}

Key words: catalytic conversion, catalyst, waste plastic, fly ash, plastic oil, hydrocarbons.

\section{Introduction}

Nowadays plastic materials are widely used and this is generating huge amount of post-use plastic wastes. Management of these plastic wastes is a serious problem. Land filling, incineration and recycling are the three available methods of utilizing plastic wastes.

Since plastic wastes are voluminous land filling requires large amount of safe depots. Hence, land filling is rather expensive. Incineration produces harmful gases like NOx, COx and SOx. These factors make plastic recycling as the most attractive method of handling waste plastics.

One method of recycling is reuse of plastics by regranulation. However, this method requires collection of pure plastics. Plastics made of polyesters and polyamides can be converted into their monomers by chemical methods. However, polyalkenes cannot be depolymerised into monomers easily. Degradation of polyalkenes into hydrocarbons has received greater attention[1-30]. Catalystic degradation has been found to be better than thermal degradation $[4,13,20,22,24,27,30]$.

Polyethylene, a widely used thermoplastic, is a polymer of ethylene and is represented as PE. The chemical formula of $\mathrm{PE}$ is $\left[\mathrm{CH}_{2} \mathrm{CH}_{2}\right]_{n}$. Based on the value of ' $\mathrm{n}$ ' polyethylene is classified into two types, viz. low density polyethylene [LDPE] and high density polyethylene [HDPE]. LDPE is generally used for making flexible materials like bags and geomembranes. HDPE is used for making containers. 
Aguado et al[25] have reported $56.3 \%$ conversion of LDPE into hydrocarbosn using zeolite beta, incorporated with aluminium and titanium, as a catalyst. Gobin and Manoy[30] have reported $95 \%$ conversion of LDPE into hydrocarbons using commercial catalyst. They have obtained $72 \%$ of oil.

Fly ash, obtained by burning lignite, is a waste product of thermal power plants. Fly ash contains silica, alumina, iron and alkali metals [31]. Fly ash has been used as a catalyst in chemical reactions $[32,33]$. In this study, we report the cracking of LDPE using fly ash as catalyst.

\section{Experimental}

\subsection{Materials and methods}

Saline bottles made up of LDPE were obtained from Raja Muthiah Medical College Hospital of our University. Fly ash was obtained from the thermal power plant at Neyveli, which is $30 \mathrm{~km}$ away from our university. The saline bottles were crushed into small pieces using crusher shown in Fig. 1. The saline bottles were loaded into the crushing chamber through the top of the crusher. The saline bottles were cut into small pieces by the cutter. An electrical motor was used to rotate the cutter. The crushed plastics were collected at the bottom. The saline bottles before and after crushing are shown in Figs $2 \mathrm{a}$ and $2 \mathrm{~b}$. The crushed material was blended with appropriate amount of catalyst wetted with water. The blend obtained was dried in air to remove the moisture content. The resultant material was subjected to degradation.

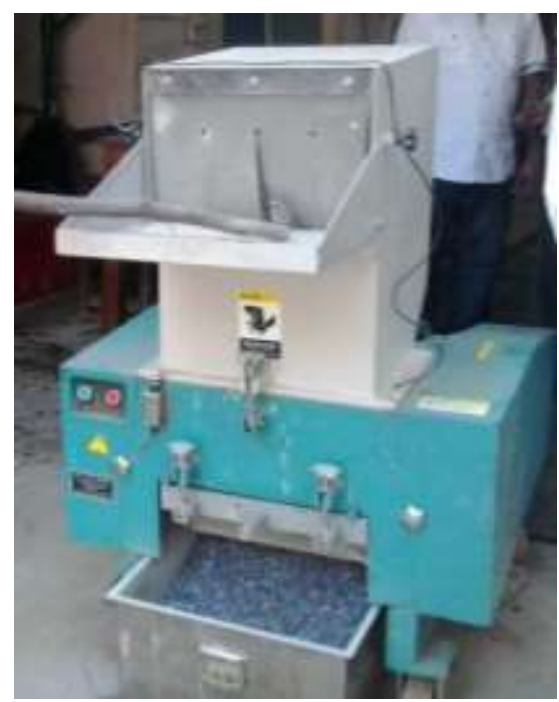

Figure 1 Crusher 


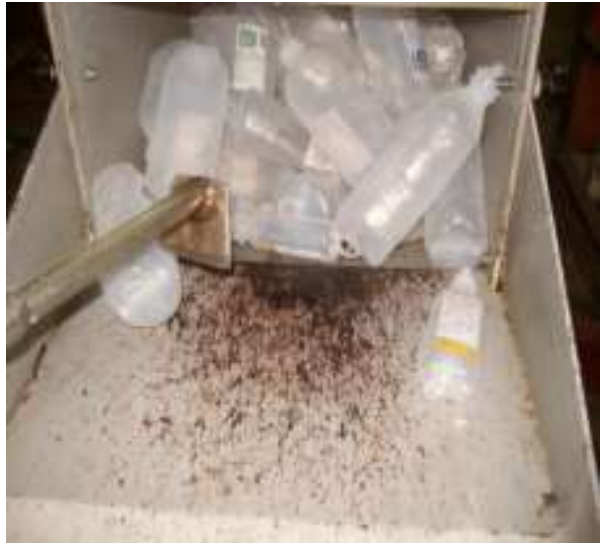

Figure (2a) Saline bottle before crushing

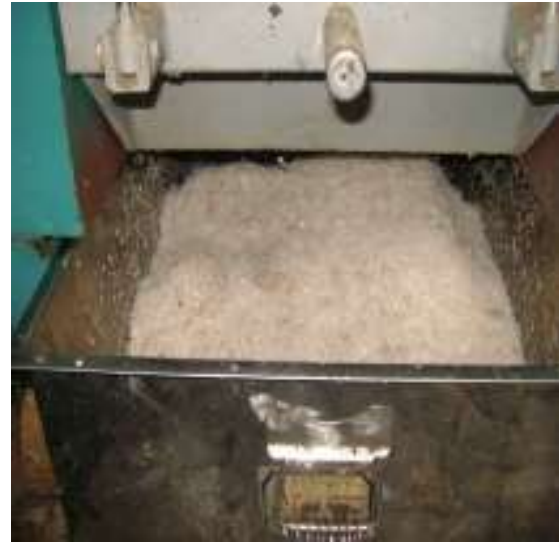

Figure (2b) Saline bottle after crushing

The sketch of the plant used for catalytic conversion is shown in Fig.3. The reactor was made of stainless steel. Heating was done electrically and the temperature inside the reaction chamber was measured using a thermocouple. The oil obtained was collected in a small tank. The uncondensed gas was analyzed using AVL Di gas 444 analyzer.

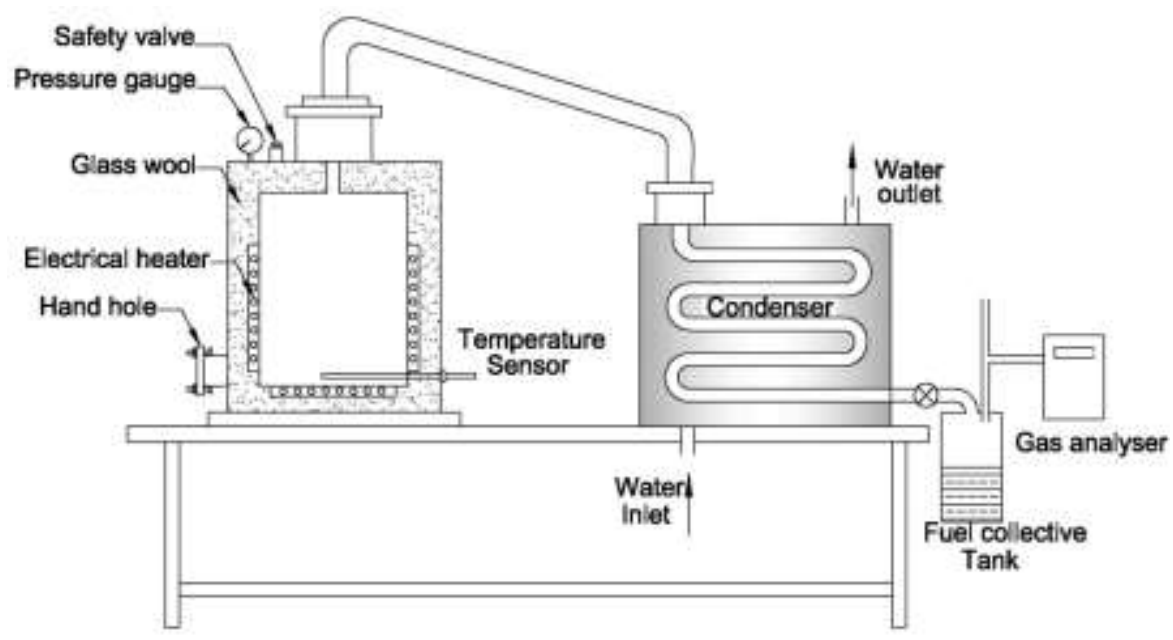

Figure 3 Waste plastic degradation plant

\subsection{Fractionation of catalytic oil}

The catalytic oil obtained was fractionated using distillation unit shown in Fig. 4. The catalytic oil was introduced into a cylindrical vessel made of stainless steel through an inlet. The vessel was placed in another vessel containing heating oil which was heated using an electrical coil. The vapour was condensed using a water condenser. The temperature of the vapour was measured using a thermocouple. The various factions were collected in different glass vessels. 


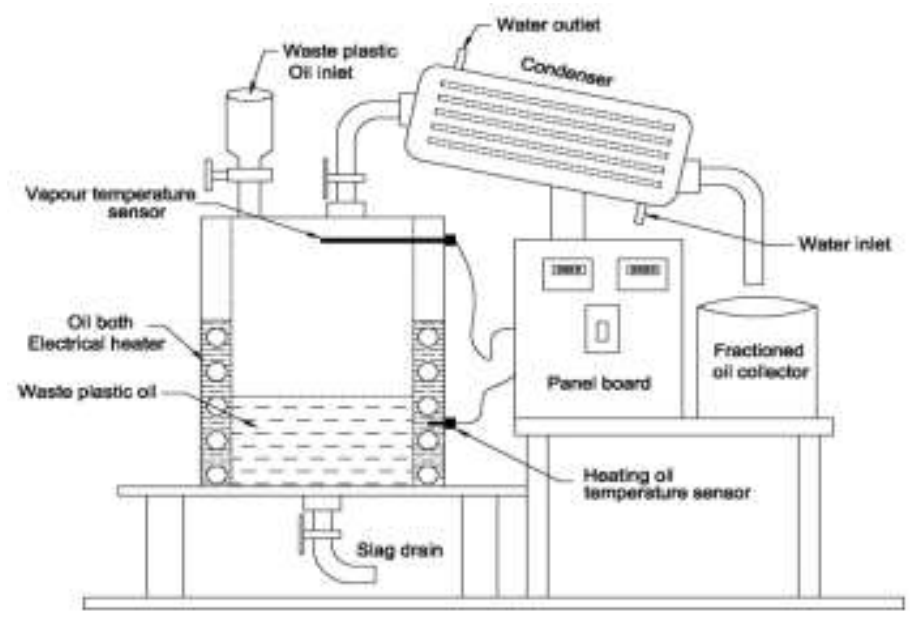

Figure 4 Distillation unit

\subsection{GCMS spectrum}

The GCMS spectrum was recorded on a Varian Saturn 2000 MSMS Spectrometer

\subsection{Physical parameters study}

Physical properties of the catalytically derived oil were determined using the following standard methods for fuel: IS-1448-P16 for density, IS-1448 P-32 for specific gravity, IS-1448-P25 for kinematic viscosity, IP-36 for flash point and fire point, IP-16 for pour point, Gross calorific value was determined as per IS-1448.

\subsection{Measurement of flame temperature}

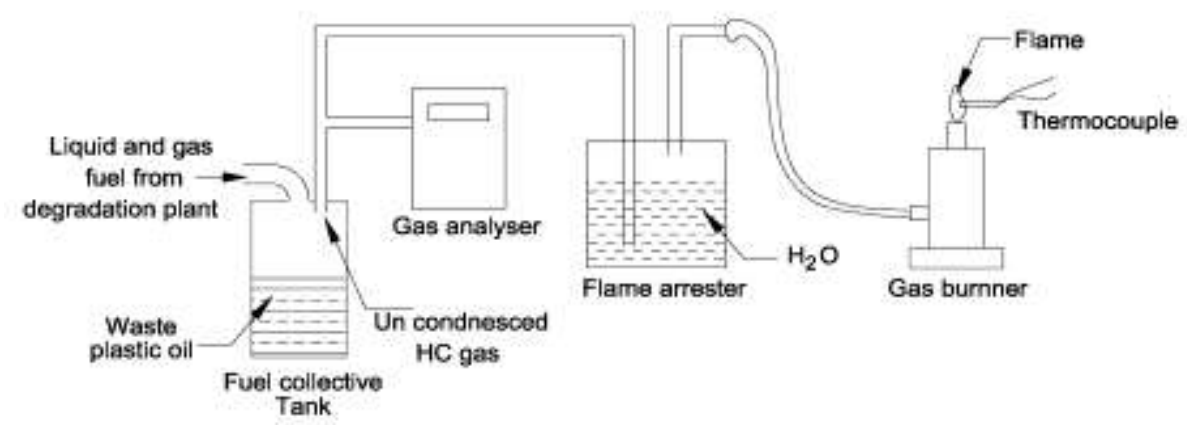

Figure 5 Measurement of flame temperature

The arrangement used for measuring the flame temperature is shown in Fig. 5. The uncondensed gas was passed through water. The washed gas was then passed through burner. The gas was burnt in the burner to get a flame. The temperature at the centre of the flame was measured using a thermocouple.

\section{Results and discussion}

\subsection{Effect of catalyst}

Degradation was carried out with $1 \mathrm{~kg}$ of the polymer. The degradation was studied without catalyst, using $100 \mathrm{~g}, 150 \mathrm{~g}$ and $200 \mathrm{~g}$ catalyst. In each experiment the temperature 
at which oil formation started and temperature at which oil formation ceased were noted. The time at which oil formation ceased was also noted. In each case the percent conversion was calculated by weighing the material remaining in the reactor after the reaction. The density of the oil was also determined in each case. All the results are given in Table 1.

For the catalytic processes the quantity of hydrocarbons evolved was measured during the course of the reaction. These results are shown in Fig. 6. The quantities of oil formed are shown in Fig. 7. The photos of the product obtained and that of fly ash are shown in Figs. 8a, $8 \mathrm{~b}, 8 \mathrm{c} \& 8 \mathrm{~d}$.

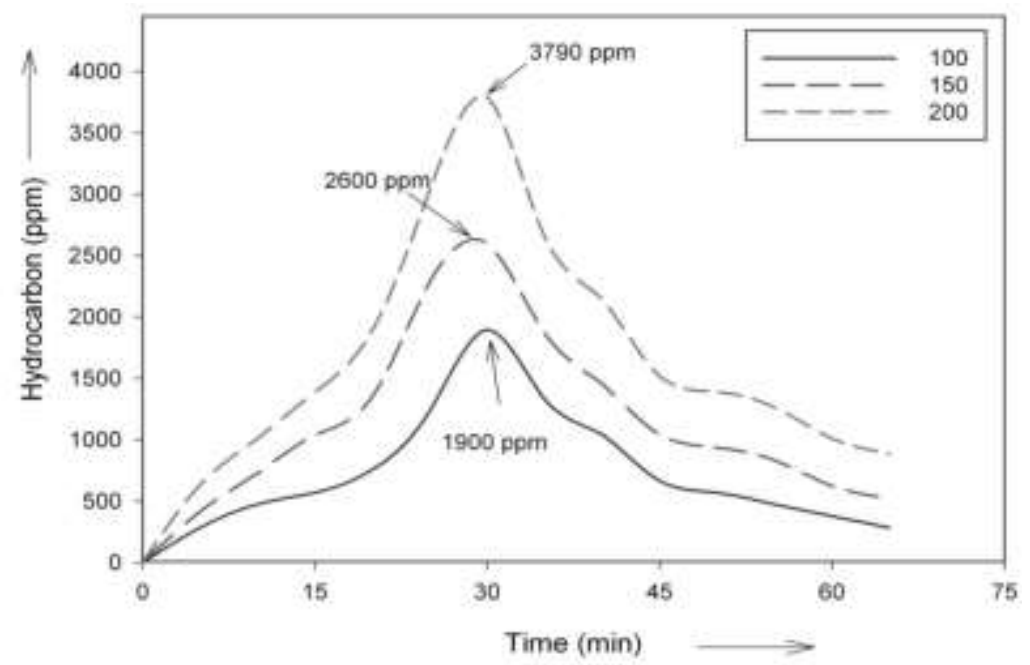

Figure 6 Oil obtained Vs Hydrocarbon (100, 150 \& 200 g catalyst)

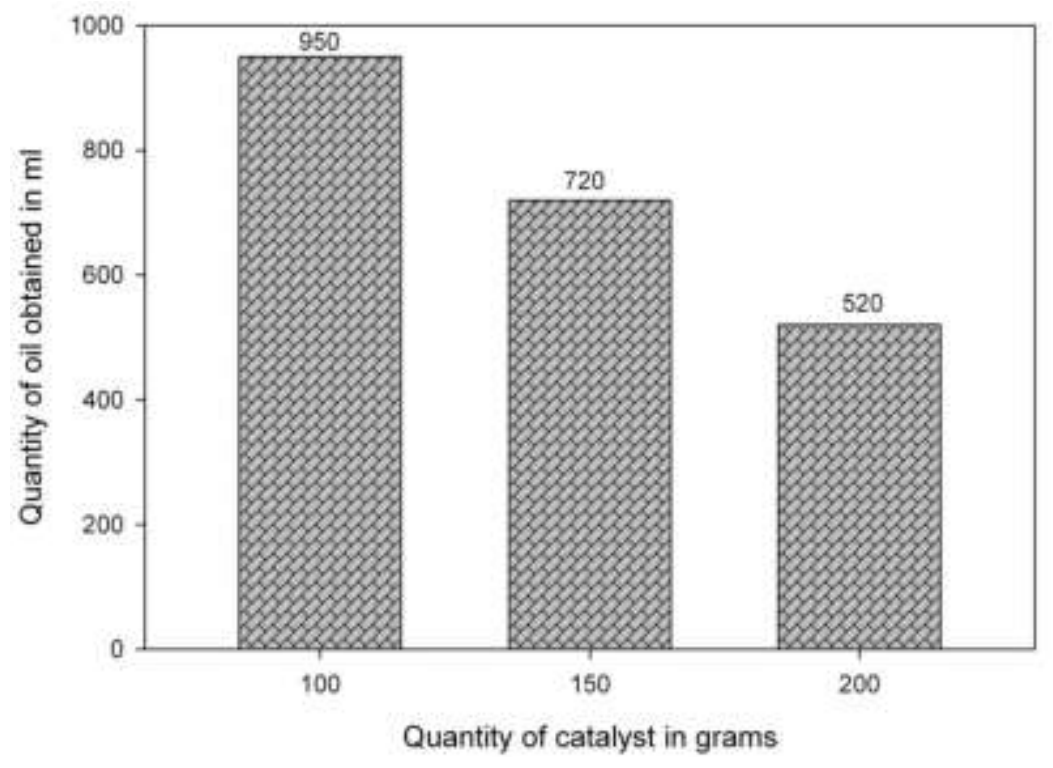

Figure 7 Oil obtained Vs catalyst added

From Table 1 it is seen that use of catalyst decreases reaction temperature and reaction time. Use of catalyst also increases the percent conversion. The amount of gaseous products also increases with the increase in the amount of catalyst. The density of the oil obtained decreases with increase in the amount of catalyst. Inspection of Fig. 8a shows that the solid mass obtained after degradation contains small amount of undegraded material. Inspection of Fig. $8 \mathrm{~b}$ and Fig. $8 \mathrm{c}$ shows that complete degradation has occurred in these cases. From Fig. $8 \mathrm{~b}$ and $8 \mathrm{c}$ it is seen that the products obtained in the reactions using $150 \mathrm{~g}$ and $200 \mathrm{~g}$ catalyst (when complete conversion has been observed) differ from that of fly ash. This shows that the catalyst is involved in the degradation of LDPE. 


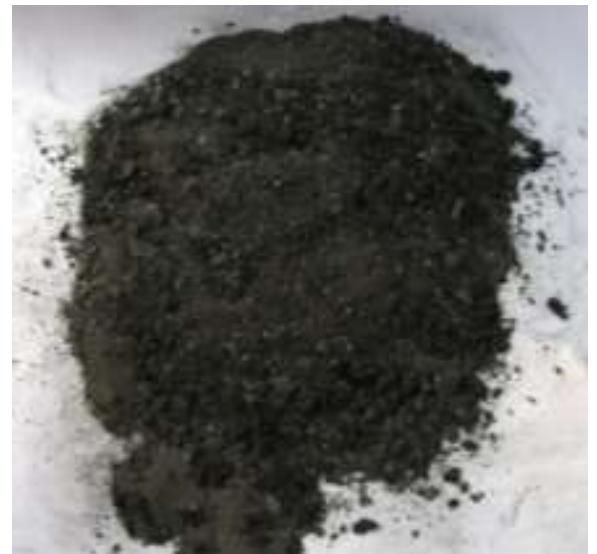

(8a) $100 \mathrm{~g}$ after degradation

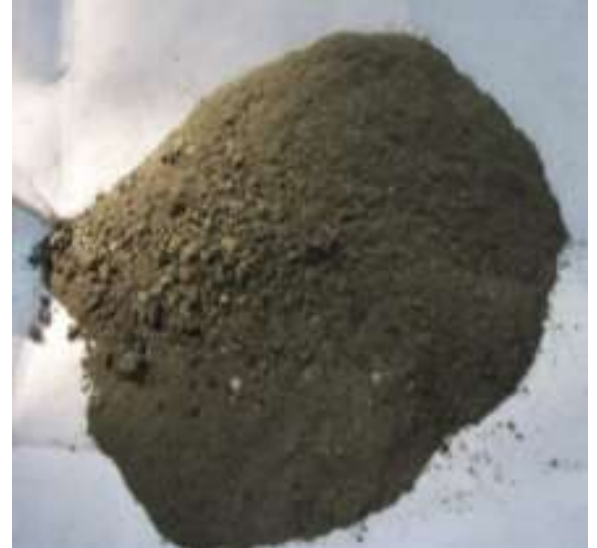

(8c)200 g after degradation

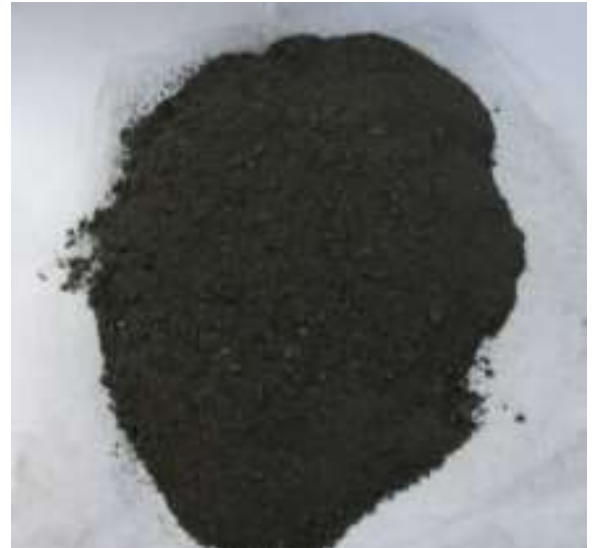

(8b) $150 \mathrm{~g}$ after degradation

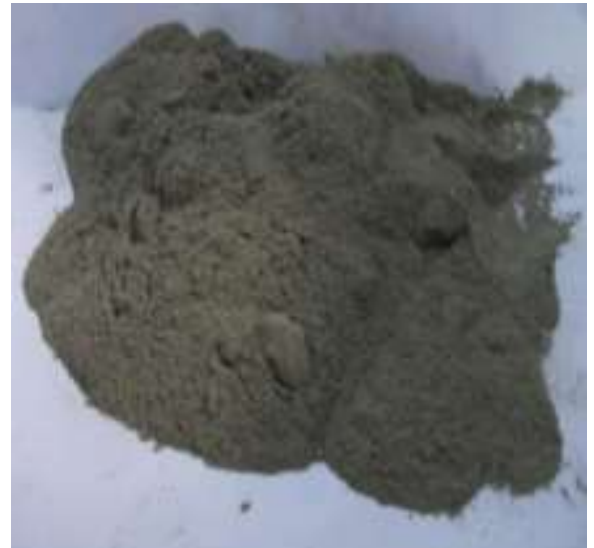

(8d) Lignite fly ash before degradation Figure 8 Photographic view of Lignite fly ash

Table 1. Physical data for degradation

\begin{tabular}{|c|c|c|c|c|c|c|}
\hline $\begin{array}{c}\text { Amount } \\
\text { of } \\
\text { catalyst } \\
(\mathrm{gm})\end{array}$ & $\begin{array}{c}\text { Reaction } \\
\text { Temperature } \\
\left({ }^{\circ} \mathrm{C}\right)\end{array}$ & $\begin{array}{c}\text { Reaction } \\
\text { time } \\
(\mathrm{min})\end{array}$ & $\begin{array}{c}\text { Conversion } \\
(\%)\end{array}$ & $\begin{array}{c}\text { Oil } \\
(\%)\end{array}$ & $\begin{array}{c}\text { Gas }^{\mathrm{b}} \\
(\%)\end{array}$ & $\begin{array}{c}\text { Density } \\
\text { of the oil } \\
\left(\mathrm{kg} / \mathrm{m}^{3}\right)\end{array}$ \\
\hline $\mathrm{Nil}$ & $230-386$ & 165 & 62 & 51 & 11 & 835 \\
\hline 100 & $210-342$ & 130 & 97 & 75 & 22 & 801 \\
\hline 150 & $190-318$ & 110 & 100 & 55 & 45 & 794 \\
\hline 200 & $170-290$ & 90 & 100 & 39 & 61 & 788 \\
\hline
\end{tabular}

a The lower temperature is temperature at which oil formation commenced and the higher temperature is the temperature at which oil formation ceased

${ }^{\mathrm{b}}$ obtained by balance.

3.2 Fractional distillation of the oil

For the catalytic processes the oil was subjected to fractional distillation. The following fractions were collected separately. Fraction boiling within $100{ }^{\circ} \mathrm{C}$, fraction boiling in the range $100-150{ }^{\circ} \mathrm{C}$ and fraction boiling in the range $150-200{ }^{\circ} \mathrm{C}$. The fraction boiling above $200{ }^{\circ} \mathrm{C}$ remained in the flask.

The amounts of various fractions collected by the fractional distillation of $1000 \mathrm{~mL}$ oil are given in Table 2. Percent recovery was calculated in each case using the following formula. 


$$
\text { Percent recovery }=\frac{\text { Total oil collected }}{1000} \times 100
$$

It is seen that in all the three cases more than $95 \%$ oil boils within $200{ }^{\circ} \mathrm{C}$. In all the three causes the major fraction is that one boiling in the range $100-150{ }^{\circ} \mathrm{C}$.

It is well known that the boiling point of hydrocarbons increases with increase in molecular mass. From Table 2 it is seen that increase in the amount of catalyst increases the amount of low boiling hydrocarbons ie., hydrocarbons with lower molecular mass.

Table 2. Amount of various fractions by fractional distillation of $1000 \mathrm{ml}$ of oil

\begin{tabular}{|c|c|c|c|c|c|}
\hline \multirow{2}{*}{ Cat/Pol } & \multicolumn{4}{|c|}{ Amount of various fractions (mL) } & Total \\
\cline { 2 - 5 } & $\begin{array}{c}\text { Fraction boiling } \\
\text { below } 100^{\circ} \mathbf{C}\end{array}$ & $\begin{array}{c}\text { Fraction boiling } \\
\text { in the range } \\
100-150^{\circ} \mathbf{C}\end{array}$ & $\begin{array}{c}\text { Fraction boiling } \\
\text { in the range } \\
\mathbf{1 5 0 - 2 0 0}{ }^{\circ} \mathbf{C}\end{array}$ & $\begin{array}{c}\text { Fraction boiling } \\
\text { above } \mathbf{2 0 0}{ }^{\circ} \mathbf{C}\end{array}$ & $\begin{array}{c}\text { recovery } \\
\text { (\%) }\end{array}$ \\
\hline 0.1 & 115 & 445 & 385 & 45 & 99 \\
\hline 0.15 & 225 & 390 & 340 & 25 & 98 \\
\hline 0.2 & 315 & 380 & 260 & 20 & 97.5 \\
\hline
\end{tabular}

\subsection{GCMS Spectrum}

GCMS spectrum was recorded for the major fraction (boiling in the range 100-150 ${ }^{\circ} \mathrm{C}$ ) obtained using in cat/pol ratio 0.1. This spectrum is shown in Fig. 9. The GC data given in Table 3. From Table 3 it is seen that this fraction is a mixture of 19 hydrocarbons with retention times varying from $6.557 \mathrm{~min}$ to $20.73 \mathrm{~min}$.

The degradation of LDPE should give a mixture of alkenes and alkanes. Alkenes of the general formula $\mathrm{C}_{n} \mathrm{H}_{2 n}$ and alkanes have the general formula $\mathrm{C}_{n} \mathrm{H}_{23+2}$. The molecular mass of an alkene is $14 n$ and that of an alkane is $(14 n+2)$ where the $n$ is the number of carbon atom. The most intense peak in the mass spectrum corresponds to mass of 97 units. This peak should be due to hydrocarbon with 7 carbon atoms. From the mass spectrum it is seen that hydrocarbons which are presents in significant amount have masses in the range 56-128 units. This masses corresponding to hydrocarbons with 4-9 carbon atoms 
International Journal of Engineering Trends and Technology (IJETT) - Volume 16 Number 5 - Oct 2014
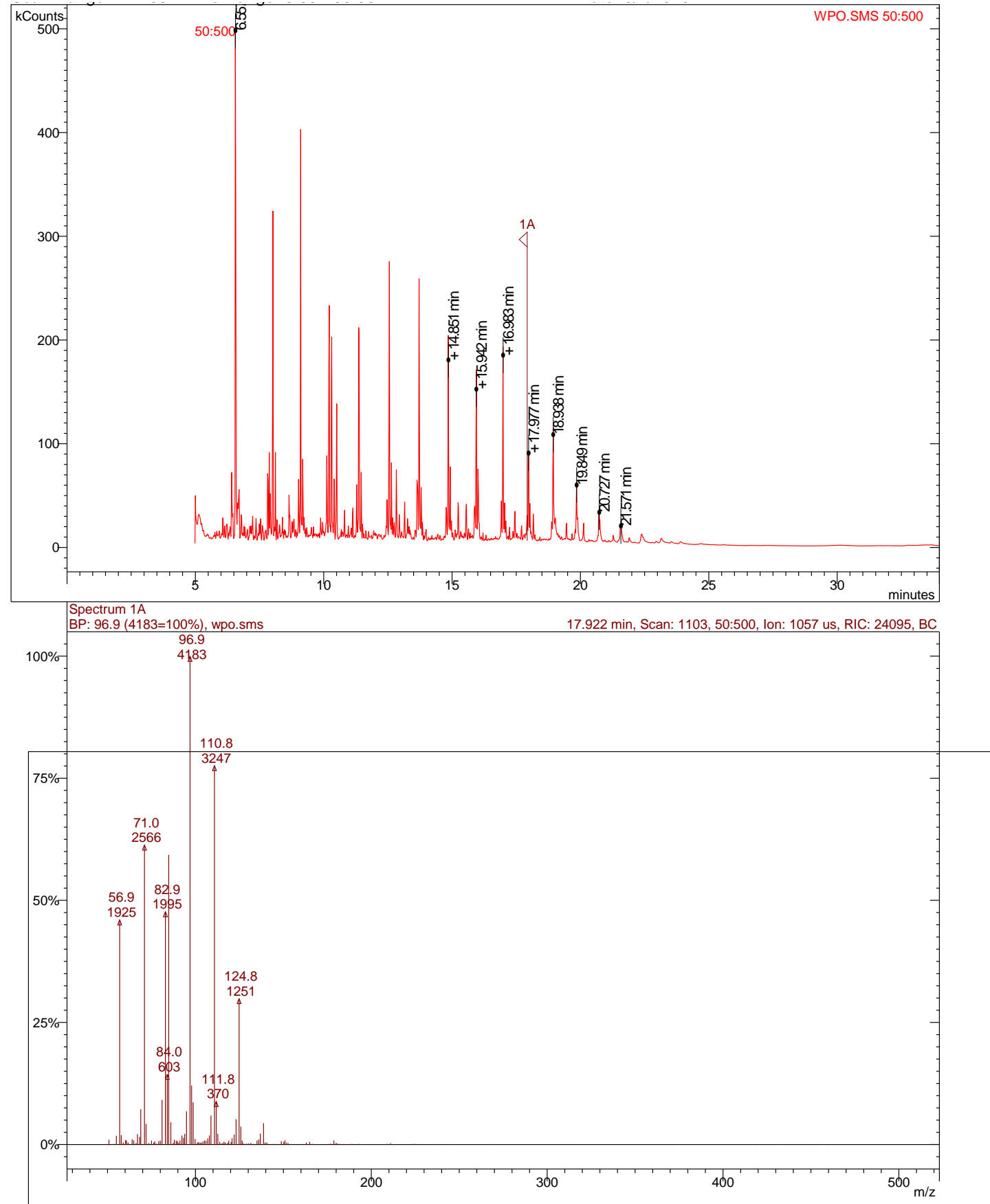

Figure 9 MS Data review active chromatogram and spectrum plots 
Table 3. Flame temperature $\left({ }^{\circ} \mathrm{C}\right)$ of the gas at various time intervals

\begin{tabular}{|c|l|l|l|l|l|}
\hline $\begin{array}{c}\text { Retention } \\
\text { Time } \\
(\mathbf{m i n})\end{array}$ & Area & \% of total & Signal /Noise & $\begin{array}{c}\text { Scan } \\
\text { description }\end{array}$ & \\
\hline 1 & 6.557 & $7.74 \mathrm{E}+06$ & 79.276 & 65 & $50: 500(2)$ \\
\hline 2 & 14.849 & 259377 & 2.657 & 53 & $50: 500(2)$ \\
\hline 3 & 14.926 & 60415 & 0.619 & 15 & $50: 500(2)$ \\
\hline 4 & 15.239 & 64275 & 0.658 & 7 & $50: 500(2)$ \\
\hline 5 & 15.553 & 63756 & 0.653 & 6 & $50: 500(2)$ \\
\hline 6 & 15.877 & 83104 & 0.851 & 13 & $50: 500(2)$ \\
\hline 7 & 15.943 & 284024 & 2.91 & 70 & $50: 500(2)$ \\
\hline 8 & 16.013 & 165129 & 1.692 & 37 & $50: 500(2)$ \\
\hline 9 & 16.919 & 60432 & 0.619 & 20 & $50: 500(2)$ \\
\hline 10 & 16.983 & 278667 & 2.855 & 110 & $50: 500(2)$ \\
\hline 11 & 17.046 & 55467 & 0.568 & 20 & $50: 500(2)$ \\
\hline 12 & 17.096 & 36446 & 0.373 & 10 & $50: 500(2)$ \\
\hline 13 & 17.446 & 53414 & 0.547 & 8 & $50: 500(2)$ \\
\hline 14 & 17.976 & 154321 & 1.581 & 53 & $50: 500(2)$ \\
\hline 15 & 18.032 & 29312 & 0.3 & 19 & $50: 500(2)$ \\
\hline 16 & 18.165 & 37270 & 0.382 & 16 & $50: 500(2)$ \\
\hline 17 & 18.938 & 179231 & 1.836 & 83 & $50: 500(2)$ \\
\hline 18 & 19.848 & 130542 & 1.337 & 50 & $50: 500(2)$ \\
\hline 19 & 20.723 & 27743 & 0.284 & 16 & $50: 500(2)$ \\
\hline
\end{tabular}

3.4 Physico-chemical properties of the various fractions

The physico-chemical properties of the three major fractions viz., fraction boiling within $100{ }^{\circ} \mathrm{C}$, fraction boiling in the range $100-150{ }^{\circ} \mathrm{C}$ and fraction boiling in the range $150-200{ }^{\circ} \mathrm{C}$ are given in Table 4 along with those of commercial diesel. From Table 4 it is seen that the properties of all the three major fractions are quite comparable to those of diesel.

Table 4. Properties of various fractions and diesel

\begin{tabular}{|c|c|c|c|c|c|c|c|c|c|c|}
\hline \multirow{4}{*}{ Property } & \multicolumn{9}{|c|}{ Boiling range } & \multirow{4}{*}{$\begin{array}{c}\text { Commercial } \\
\text { diesel }\end{array}$} \\
\hline & \multirow{2}{*}{\multicolumn{3}{|c|}{$\begin{array}{c}<100^{\circ} \mathrm{C} \\
\text { Cat/pol ratios }\end{array}$}} & \multirow{2}{*}{\multicolumn{3}{|c|}{$\begin{array}{c}100-150^{\circ} \mathrm{C} \\
\text { Cat/pol ratios }\end{array}$}} & \multirow{2}{*}{\multicolumn{3}{|c|}{$\begin{array}{c}150-200^{\circ} \mathrm{C} \\
\text { Cat/pol ratios }\end{array}$}} & \\
\hline & & & & & & & & & & \\
\hline & 0.1 & 0.15 & 0.2 & 0.1 & 0.15 & 0.2 & 0.1 & 0.15 & 0.2 & \\
\hline $\begin{array}{l}\text { Specific gravity of } \\
15^{\circ} \mathrm{C}\end{array}$ & 0.774 & 0.773 & 0.773 & 0.801 & 0.799 & 0.795 & 0.820 & 0.817 & 0.797 & 0.82 \\
\hline $\begin{array}{l}\text { Kinematic viscosity } \\
\text { at } 40^{\circ} \mathrm{C} \text { (Cst) }\end{array}$ & 1.86 & 1.81 & 1.76 & 2.74 & 2.64 & 2.04 & 3.99 & 3.45 & 2.51 & 2.5 \\
\hline Flash point ${ }^{\circ} \mathrm{C}$ & 33 & 31 & 32 & 34 & 36 & 34 & 46 & 41 & 38 & 34 \\
\hline Fire point ${ }^{\circ} \mathrm{C}$ & 36 & 35 & 35 & 38 & 42 & 38 & 52 & 48 & 43 & 43 \\
\hline Poor point ${ }^{\circ} \mathrm{C}$ & $<-4$ & $<-4$ & $<-3$ & $<-3$ & $<-3$ & $<-3$ & $<-2$ & $<-2$ & $<-4$ & - \\
\hline Calorific value & 42837 & 42753 & 42805 & 42716 & 41919 & 42721 & 42749 & 41870 & 42614 & 42373 \\
\hline Cetane number & 51.8 & 51.6 & 51.8 & 51.4 & 51.4 & 51.3 & 50.9 & 51.0 & 51.2 & 50.0 \\
\hline
\end{tabular}

3.5 Temperature of the flame obtained by burning the gas 
At periodic intervals after the commencement of the reaction the gas was burnt in a burner and the temperature of the flame was noted using a thermocouple. The observed flame temperatures at various time intervals are given in Table 5.

Table 5. Flame temperature $\left({ }^{\circ} \mathrm{C}\right)$ of the gas at various time intervals

\begin{tabular}{|c|c|c|c|}
\hline \multirow{2}{*}{ Cat/Pol } & \multicolumn{3}{|c|}{ Time(min) } \\
\cline { 2 - 4 } & $\mathbf{1 5}$ & $\mathbf{3 0}$ & $\mathbf{4 5}$ \\
\hline 0.1 & 410 & 574 & 340 \\
\hline 0.15 & 484 & 630 & 415 \\
\hline 0.2 & 535 & 725 & 472 \\
\hline
\end{tabular}

From Fig. 6 it is seen that the amount of gaseous hydrocarbons released is maximum after $30 \mathrm{~min}$. The observed flame temperatures suggest that the amount of hydrocarbons released is maximum after $30 \mathrm{~min}$. The photos of the flames obtained by burning the gas after $30 \mathrm{~min}$ are shown in figures 10a, 10b and 10c. It is seen that the flame is more intense when cat/pol ratio is 0.2 . From Fig. 6 it is seen that the amount of gaseous hydrocarbons increases with increase in cat/pol ration. The observed flame temperatures and intensities of the flam confirm this.
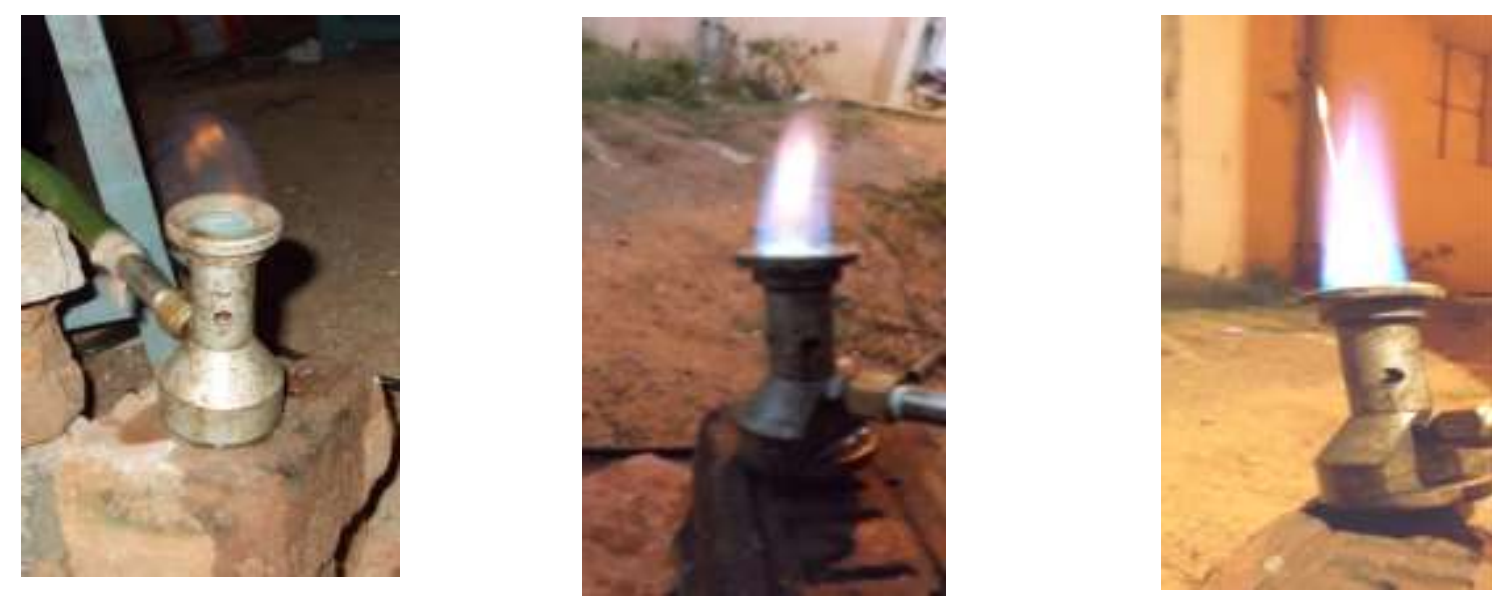

Figure 10 Photographic view of hydrocarbon burring using $100 \mathrm{~g}, 150 \mathrm{~g}$ and $200 \mathrm{~g}$ catalyst

\section{CONCLUSION}

This study shows that LDPE can be completely converted into hydrocarbons using fly ash as a catalyst. When cat/pol ratio is $0.197 \%$ conversion is observed with $75 \%$ oil formation. Though increase in cat/pol ratio results in $100 \%$ conversion the yield the oil is decreased by increase in cat/pol ratio. The fractions of the plastic oil can be used as substitute for diesel. The flame temperature of the flame obtained by burning the gas is higher when cat/pol ratio is 0.2 . This is because of more gaseous hydrocarbons are released when cat/pol ratio is 0.2 .

\section{REFERENCES}

[1] Y.H. Lin, M.H. Yang, T.F. Yeh, M.D. Ger, "Catalytic degradation of high density polyethylene over mesoporous and microporous catalysts in a fluidized-bed reactor" Polymer Degradation and Stability, 86 (2004), pp. 121-128.

[2] I.C. Neves, G. Botelho, A.V. Machado, P.Rebelo, S. Ramoa, M.F.R. Pereira, "Feedstock recycling of polyethylene over AlTuD-1 mesoporous Catalyst" Polymer Degradation and Stability, 92 (2007), pp. 1513-1519.

[3] K. Gobin, G. Manos, "Thermogravimetric study of polymer catalystic degradation over microporous materials" Polymer Degradation and Stability, 86 (2004), pp. 225-231 
[4] N. Miskolczi, L. Bartha, G. Deak, B. Jover, D. Kallo, "Thermal and thermo-catalytic degradation of highe-density polyethylene waste" Journal of Analytical and Applied Pyrolysis, 72 (2004), pp. 235-242.

[5] J.F. Mastral, C. Berrueco, M. Gea, J. Ceamanos, "Catalytic degradation of high density polyethylene over nano crystalline HZSM-5 Zeolite" Polymer Degradation and Stability, 91 (2006), pp. 3330-3338.

[6] G. Manos, I.Y. Yusof, N. Papayannakos, N.H. Gangas, "Catalytic cracking of polyethylene over clay catalysts. Comparison with an ultrastable Y zeolite" Industrial \& Engineering Chemistry Research, 40 (2001), pp. 2220-2225.

[7] J. Mosio-Mosiewski, M. Warzala, I. Morawski, T. Dobrzanski, "High pressure catalytic and thermal cracking of polyethylene fuel process" Journal of Technology, 88 (2007), pp. 359-364.

[8] I.C. Neves, G. Botelho, A.V. Machodo, P. Rebelo, "Catalytic degradation of polyethylene; An evaluation of the effect of dealuminated Y Zeolites using thermal analysis" Materials Chemistry and Physics, 104 (20070, pp. 5-9.

[9] G. Manos, A. Garforth, J. Dwyer, "Catalytic degradation of high-density polyethylene on an ultrastable-Y zeolite. Nature of initial polymer reactions, pattern of formation of gas and liquid products, and temperature effects" Industrial \& Engineering Chemistry Research, 39 (2000), pp. $1203-1208$.

[10] K.H. Lee, D.H. Shin, "Catalystic degradation of waste polyolefinic polymers using spent FCC catalyst with various experimental variables" Korean Journal of Chemical Engineering, 20 (2003), pp. 89-92.

[11] G. Elordi, M. Olazar, G. Lopez, M. Amutio, M. Artetxe, R. Aguado, "Catalytic pyrolysis of HDPE in continuous mode over zeloite catalysts in a conical spouted bed reactor" Journal of Analytical and Applied Pyrolysis, 85 (2009), pp. 345-351.

[12] G. Elordi, M. Olazar, R. Aguado, G. Lopez, M. Arabiourrutia, J. Bilbao, "Catalytic pyrolysis of high density polyethylene in a conical spouted bed reactor" Journal of Analytical and Applied Pyrolysis, 79 (2007), pp. 450-455.

[13] F.J. Mastral, E. Esperanza, C. Berrueco, M. Juste, J. Ceamanos, "Fluyidized bed thermal degradation products of HDPE in an inert atmosphere and in air/nitrogen mixtures" Journal of Analytical and Applied Pyrolysis, 70 (2003), pp. 1-17.

[14] M.R. Jan, J. Shah, H. Gulab, "Degradation of waste high-density polyethylene into fuel oil using basic catalyst" Journal of Fuel, 89 (2010), pp. 474-480.

[15] M.R. Jan, J. Shah, H. Gulab, "Catalytic degradation of waste high-density polyethylene into fuel products using $\mathrm{BaCO}_{3}$ as a catalyst" Fuel processing Technology, 91 (2010), pp. 1428-1437.

[16] R.A. Garcia, D.P. Serrano, D. Otero, "Catalytic cracking of HDPE over hybride zeolitic-mesoporous materials" Journal of Analytical and Applied Pyrolysis, 74 (2005), pp. 1-17.

[17] G. Manos, A. Garforth, J. Dwyer, "Catalytic degradation of high-density polyethylene over different zeolitic structures" Industrial \& Engineering Chemistry Research, 39 (2000), pp. 1198-1202.

[18] G. Luo, T. Suto, S. Yasu, K. Kato, "Catalytic degradation of high density polyethylene and polypropylene into liquid fuel in a powder-particle fluidized bed" Polymer Degradation and Stability, 70 (2000), pp. 97-102.

[19] Y. Sakata, M. Azhar-Uddin, A.Muto, Y. Kanada, K. Koizumi, K. Murata, "Catalytic degradation of polyethylene into fuel oil over mesoporous silica (KFS-16) catalyst" Journal of Analytical and Applied Pyrolysis, 43 (1997), pp. 15-25.

[20] G.J.T. Fernandes, V.J. Fernandes J.R, A.S. Araujo, "Catalytic degradation of polyethylene over SAPO-37 molecular sieve" Catalysis Today, 75 (2002), pp. 233-238.

[21] W. Ding, J. Liang, L. Anderson, "Thermal and catalytic degradation of high density polyethylene and commingled post-consumer plastic waste" Fuel Processing Technology, 51 (1997), pp. 47-62.

[22] M. R. Jan, J. Shah, H. Gulab, "Catalytic conversion of waste high density polyethylene into useful hydrocarbons" Journal of Fuel, 105, (2013), pp 595-602.

[23] Selahan Karagoz, JaleYanik, Suat Ucar, Mehmet Saglam, Chunshan Song, "Catalytic and thermal degradation of high-density polyethylene in vacuum gas oil over non-acidic and acidic catalysts" Journal of Applied catalysis 245 (2003) pp. 51-62.

[24] Jerzy Walendziewski, "Engine fuel derived from waste plastics by thermal treatment" Journal of Fuels, 81 (2002) pp. 473-481.

[25] J. Aguado, D.P. Serrano, J.M. Escola, E. Garagorri, J.A. Fernandez, "Catalytic conversion of polyolefin's into fuels over zeolite beta" Journal of Polymer Degradation and stability 69(2000) pp. 11-16.

[26] Ikusei Nakamura, Kaoru Fujimoto, "Development of new disposale catalyst for waste plastics treatment for high quality transportation fuel" Journal of Catalysis Today, 27 (1996) pp. 174-179.

[27] Jerzy Walendziewski, Mieczyslaw Steininger, "Thermal and catalytic conversion of waste polyolefines" Journal of Catalysis Today, 65 (2001)pp. 323-330.

[28] N. Miskolczi, L. Bartha, G. Deak, B. Jover, "Thermal degradation of municipal plastic waste for production of fuel-like hydrocarbons" Journal of Polymer degradation and stability 86 (2004) pp. 357-366.

[29] Mohammad Farhat Ali, Mohammad Nahid Siddiqui, "Thermal and catalytic decomposition dehavior of PVC mixed plastic waste with petroleum residue" journal of Annalytical and Applied Pyrolyysis, 74 (2005) pp. 282-289.

[30] Karishma Gobin, George Manos, "Polymer degradation to fuels over microporous catalysts as novel tertiary plastic recycling method", Journal of Polymer Degradation and stability 83(2004), pp 267-279.

[31] D. Khale and R. Chaudhary, "Mechanism of geopolymerization and factors influencing its development", a review, J Mater Sci., 10 (2007) pp. 729-746.

[32] M.M.A. Abdullah, K. Hussin, M. Bnhussain, K. N. Ismail and W. M. W. Ibrahim, " Mechanism and chemical reaction of fly ash Geopolymer cement - A review”, Int. J. Pure Appl. Sci. Technol., 6(1) (2011) pp. 35-44.

[33] Anita Sharma, Stuti Katara, Sakshi Kabra and Ashu Rani, "Acid activated fly ash as a novel solid acid catalyst for Esterification of Acetic Acid”, Indian Journal of Applied Research, 3(4) (2013) pp. 37-39. 